\title{
ACTION OF NISIN AND HIGH PH ON GROWTH OF STAPHYLOCOCCUS AUREUS AND SALMONELLA SP. IN PURE CULTURE AND IN THE MEAT OF LAND CRAB (UCIDES CORDATUS)
}

\author{
Teresa Cristina S. de Lima Grisi ${ }^{1}$; Krystyna Gorlach-Lira ${ }^{2 *}$ \\ ${ }^{1}$ Universidade Federal da Paraiba, João Pessoa, PB, Brasil; ${ }^{2}$ Departamento de Biologia Molecular, \\ Universidade Federal da Paraiba, João Pessoa, PB, Brasil.
}

Submitted: March 16, 2004; Returned to authors for corrections: December 08, 2004; Approved: June 02, 2005

\begin{abstract}
The aim of this study was to evaluate the potential of nisin and high $\mathrm{pH}$ to inhibit the growth of Staphylococcus aureus and Salmonella sp. in broth culture and when inoculated into meat of land crab. In pure cultures, the growth of $S$. aureus was strongly inhibited by nisin and the growth of Salmonella sp. was inhibited by nisinEDTA $(20 \mathrm{mM})$. The inhibition of $S$. aureus lasted for eight hours and Salmonella sp. growth was inhibited throughout the experiment $\left(24 \mathrm{~h}\right.$ ). The high $\mathrm{pH}$ ( $\mathrm{pH} 10.0$ and 11.0 with $\mathrm{NaHCO}_{3}-\mathrm{NaOH}$ buffer) was very effective for in vitro inhibition of $S$. aureus and Salmonella sp. Nisin and high $\mathrm{pH}$, when applied to the contaminated meat, did not yield the same effect. Nisin was not effective in preventing growth of both pathogens in the crab meat, while $\mathrm{pH} 10.0$ showed significant inhibitory effect on Salmonella sp. The results suggest that high $\mathrm{pH}$ has a potential as antibacterial agent, and may be useful in chemical preservation of crab meat.
\end{abstract}

Key words: crab meat, nisin, high $\mathrm{pH}$, Staphylococcus aureus, Salmonella sp.

\section{INTRODUCTION}

The land crab (Ucides cordatus) is one of the principal species of crustaceans living in the Atlantic Ocean mangroves, inhabiting the large coastal area extending from the south of USA to the south of Brazil. The meat of this crab has a big market in Brazil, principally in Northeastern states, as well as in other South and Central American countries. The crab meat offered to consumers is often highly contaminated with bacteria due to inadequate processing and storage techniques $(2,4,5)$. The microbiological status of the meat is influenced by its quality, including the contamination level of the crab living area, and its subsequent handling and processing. Preservation of fresh crab meat currently involves its freezing and maintenance in low temperatures. Use of chemicals for washing the crab meat before freezing to prevent or inhibit microbial growth would be a way to improve the product quality.
The use of nisin, the bacteriocin produced by Lactococcus lactis subsp. lactis, is successfully used as antibacterial agent in various food products. Nisin affects several Gram-positive bacteria such as Listeria spp., Staphylococcus spp. but does not inhibit the majority of Gram-negative bacteria $(1,6,11)$. Nisin showed to be efficient in inactivating Gram-negative bacteria when used together with chelating agents (EDTA), causing an aberration in cell membrane lipopolisaccharyde component (17).

High $\mathrm{pH}$ treatment has showed to kill Gram-negative $(3,12,15)$ and some Gram-positive bacteria $(8,18)$. The use of high $\mathrm{pH}$ $\mathrm{NaHCO}_{3}-\mathrm{NaOH}$ buffer solutions inhibited effectively some Gram-negative bacteria causing rapid death of Salmonella enteritidis and Escherichia coli, but with less influence on the growth rate of Listeria monocytogenes $(12,18)$.

In the present study we evaluated the effect of nisin and high $\mathrm{pH}$ on Staphylococcus aureus and Salmonella sp. in pure

*Corresponding Author. Mailing address: Universidade Federal da Paraíba, Centro de Ciências Exatas e da Natureza - CCEN, Departamento de Biologia Molecular, Campus I, Cidade Universitária. 58059-900, João Pessoa, PB, Brasil. E-mail: krysgl@dbm.ufpb.br 
culture and inoculated in the meat of the land crab (Ucides cordatus).

\section{MATERIALS AND METHODS}

\section{Bacterial strains}

We used Staphylococcus aureus strain ETP33 (Ucides cordatus meat isolate) and Salmonella sp. STP221 (mangrove water isolate) of the collection of the Molecular Biology Department of Federal University of Paraiba, PB, Brazil.

\section{Chemicals}

Purified nisin (Sigma) was used in the present work. The nisin stock solution was prepared by dissolving $0.1 \mathrm{~g}$ of nisin in $10 \mathrm{~mL}$ of $0.02 \mathrm{~N} \mathrm{HCl}$ (17). This solution was used to prepare the required nisin concentrations. The $\mathrm{NaHCO}_{3}-\mathrm{NaOH}$ buffer

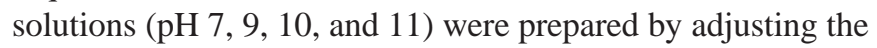
pH of $0.05 \mathrm{M} \mathrm{NaHCO}_{3}$ with $10 \mathrm{~N} \mathrm{NaOH}$ (12).

\section{Effect of antibacterial agents on pure cultures}

S. aureus and Salmonella sp. were grown in the BHI broth (Difco Laboratories, Detroit, Mich.) at $37^{\circ} \mathrm{C}$ for 24 hours. An $0.1-\mathrm{mL}$ aliquot of this culture was used to inoculate the BHI medium with the additives (final volume $15 \mathrm{~mL}$ ). The BHI medium was reconstituted in distilled water and nisin was added in the following concentrations: $0,300,600$, and $1200 \mu \mathrm{g} / \mathrm{mL}$ for the $S$. aureus control; and $0,100,300$, and $600 \mu \mathrm{g} / \mathrm{mL}$ of nisin in combination with $20 \mathrm{mM}$ of EDTA(Merck, Darmstad, Germany) for the control of Salmonella sp. For the high $\mathrm{pH}$ antibacterial activity assay the BHI medium was reconstituted in $\mathrm{NaHCO}_{3}$ $\mathrm{NaOH}$ buffer at $\mathrm{pH} 7,9,10$, and 11 . The $\mathrm{BHI}$ medium prepared in distilled water without additives was the control. The cultures were incubated at $37^{\circ} \mathrm{C}$ for 24 hours. All tests were done in triplicate. The growth of cultures was examined by spectrophotometric monitoring of optical density at $580 \mathrm{~nm}$ (O.D. $580 \mathrm{~nm}$ ) at the following intervals: 0, 1, 2, 4, 6, 8, and 24 hours, using the respective non-inoculated medium as a blank.

\section{Inoculation of crab meat with $S$. aureus and Salmonella sp.}

Fresh land crab meat (Ucides cordatus) was obtained at the free market and frozen until used. The crab meat was autoclaved at $121^{\circ} \mathrm{C}$ for 25 minutes and cooled to $4^{\circ} \mathrm{C}$ in the refrigerator. The bacterial strains were inoculated in $900 \mathrm{~mL}$ of the BHI medium, incubated at $37^{\circ} \mathrm{C}$ for 24 hours, and centrifuged (Sorvall RC5C, Wilmington, USA) for 15 minutes at $6000 \mathrm{rpm}\left(4^{\circ} \mathrm{C}\right)$. The supernatant was discarded and the cells were resuspended in $900 \mathrm{~mL}$ of sterile distilled water. The $900 \mathrm{~mL}$ of the $S$. aureus or Salmonella sp. cell suspension was added to $900 \mathrm{~g}$ of meat (inoculation level $10^{7}-10^{8} \mathrm{CFU} / \mathrm{g}$ ) and mixed using a sterile glass rod for $2 \mathrm{~min}$. Each strain was used separately. The meat suspension inoculated with bacteria was then poured into a large funnel with gauze and drained into a 1-liter graduated cylinder. The meat was pressed in a sterile pestle until $900 \mathrm{~mL}$ of the fluid (original volume of inoculum) was recovered.

\section{Treatment of inoculated meat with antibacterial agents and microbiological analysis}

The crab meat inoculated with bacterial strains was divided into three lots of $300 \mathrm{~g}$ for the bacterial agents treatment. The following sterile solutions were used to wash the meat: distilled water (control), $600 \mu \mathrm{g} / \mathrm{mL}$ of nisin for $S$. aureus, $100 \mu \mathrm{g} / \mathrm{mL}$ of nisin with $20 \mathrm{mM}$ of EDTA for Salmonella sp., and $\mathrm{NaHCO}_{3}-$ $\mathrm{NaOH}$ buffer at $\mathrm{pH} 10$. Each solution $(300 \mathrm{~mL})$ was added separately to individual lots of crab meat in a $600-\mathrm{mL}$ beaker, mixed and kept at $4^{\circ} \mathrm{C}$ for $30 \mathrm{~min}$. The meat was then drained as described above. Each $300 \mathrm{~g}$ of treated meat sample was divided into 20-g aliquots and placed into sterile Petri dishes. The meat was stored at $4^{\circ} \mathrm{C}$ and the duplicate samples were monitored for the numbers of $S$. aureus or Salmonella sp. before washing and after $6,24,48,72,96$, and 120 hours of storage at $4^{\circ} \mathrm{C}$. The number of bacteria in the inoculated meat was determined by homogenizing 20-g sample of meat with $180 \mathrm{~mL}$ of $1 \%$ peptone and spread plating dilutions onto a Baird-Parker medium (Difco Laboratories, Detroit, Mich.) for S. aureus and an XLD medium (Oxoid, UK) for Salmonella sp. The plates were incubated at $35^{\circ} \mathrm{C}$ for $24-48$ hours. The $\mathrm{pH}$ of the meat during the storage of the crab meat at $4^{\circ} \mathrm{C}$ was measured.

In the bioassay, the significant differences obtained in bacterial growth rate among treatments with main effects of treatment type and incubation/storage time were examined statistically by two-way ANOVA. These statistical tests were done for broth culture assay and crab meat treatment experiment with the aid of a computer program package (Statistica, version 5).

\section{RESULTS}

\section{Broth culture assay}

In untreated BHI medium the growth of S. aureus and Salmonella sp. was characterized by a short lag phase followed by the rapid growth period, entering the stationary phase after 4 hours of incubation. ANOVA revealed that the growth of both pathogens depended on the concentration of nisin/nisin + EDTA and pH level, as well as the time of incubation (Table 1). Significant inhibition $(\mathrm{P}<0.001)$ of $S$. aureus in pure culture was observed for all nisin concentrations $(100-300 \mu \mathrm{g} / \mathrm{mL})$ used, but only during 8 hours of incubation (Fig. 1). The inhibition phase was followed by a period of a rapid growth of the strain, achieving levels similar to those of the control after 24 hours. On the other hand, the nisin in concentrations ranging from 300 to $1200 \mu \mathrm{g} / \mathrm{mL}$ and $20 \mathrm{mM}$ EDTA showed strong inhibitory effect on Salmonella sp., that continued over the 24 hours of the experiment (Fig. 2). Slow increase of Salmonella sp. cell numbers was detected in all samples; however, its level was significantly 
Table 1. Results of two-way ANOVA on the S. aureus and Salmonella sp. growth in broth culture assay.

\begin{tabular}{|c|c|c|c|c|c|c|c|c|}
\hline \multirow{2}{*}{ Variable } & \multicolumn{4}{|c|}{ S. aureus } & \multicolumn{4}{|c|}{ Salmonella sp. } \\
\hline & df & MS & $\mathrm{F}$ & $\mathrm{P}$ & df & MS & $\mathrm{F}$ & $\mathrm{P}$ \\
\hline Nisin $^{\mathrm{a}} /$ Nisin-EDTA ${ }^{\mathrm{b}}$ & 3 & 1.071 & 16038.06 & $0.000^{*}$ & 3 & 0.564 & 3207.21 & $0.000 *$ \\
\hline Time & 6 & 1.119 & 16762.53 & $0.000^{*}$ & 6 & 0.395 & 2249.08 & $0.000 *$ \\
\hline Nisin $x$ Time & 18 & 0.151 & 2264.47 & $0.000^{*}$ & 18 & 0.050 & 286.96 & $0.000 *$ \\
\hline $\mathrm{pH}$ & 4 & 1.137 & 5122.34 & $0.000^{*}$ & 4 & 1.433 & 203.10 & $0.000 *$ \\
\hline Time & 6 & 0.498 & 2246.40 & $0.000^{*}$ & 6 & 0.834 & 118.19 & $0.000 *$ \\
\hline pH x Time & 24 & 0.126 & 567.53 & $0.000 *$ & 24 & 0.190 & 26.93 & $0.000 *$ \\
\hline
\end{tabular}

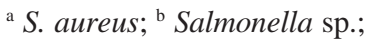

Mean Squares (MS) and F values are indicated with degrees of freedom (df);

* Significant at $1 \%$ level.

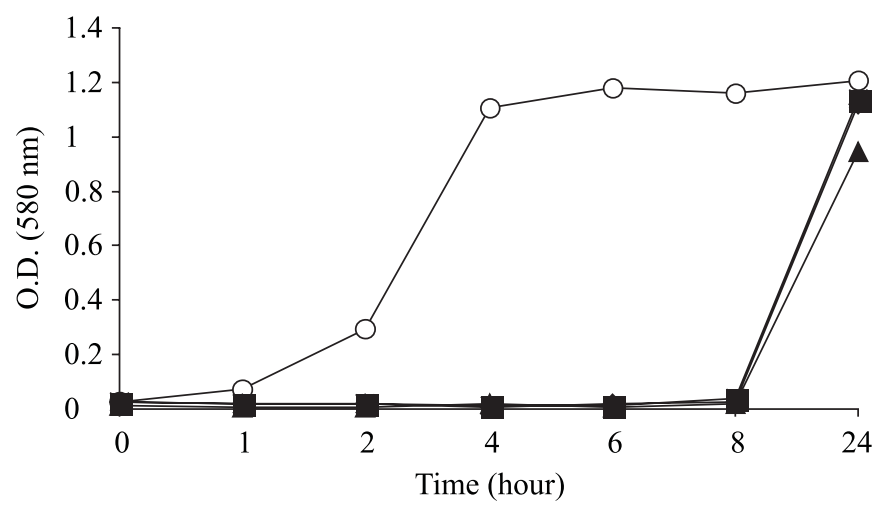

Figure 1. Growth of Staphylococcus aureus in the BHI broth without additives (control) (O) and supplemented with $100 \mu \mathrm{g} /$ $\mathrm{ml}(\boldsymbol{\square}), 300 \mu \mathrm{g} / \mathrm{ml}(\bullet)$ and $600 \mu \mathrm{g} / \mathrm{ml}(\boldsymbol{\Delta})$ of nisin.

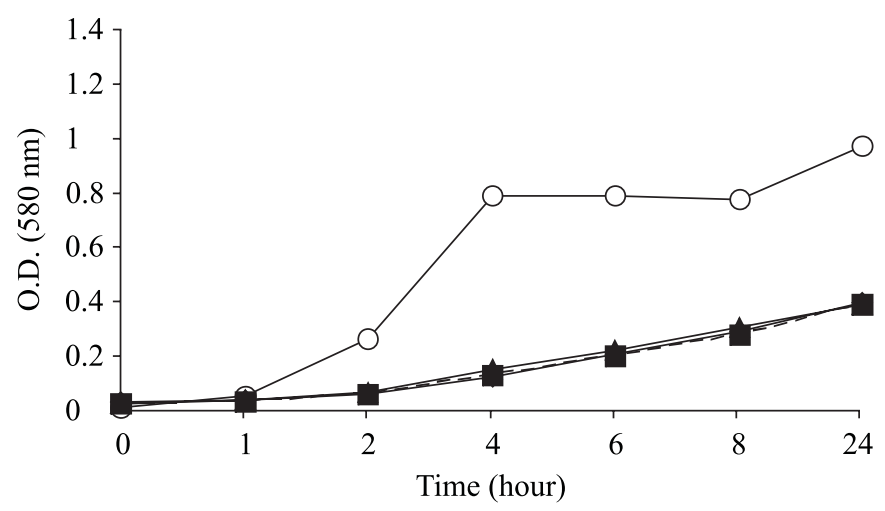

Figure 2. Growth of Salmonella sp. in BHI broth without additives (control) (O) and supplemented with $300 \mu \mathrm{g} / \mathrm{ml}(\boldsymbol{\square})$, $600 \mu \mathrm{g} / \mathrm{ml}(\bullet)$ and $1200 \mu \mathrm{g} / \mathrm{ml}(\boldsymbol{\Delta})$ of nisin in combination with $20 \mathrm{mM}$ of EDTA. lower $(\mathrm{P}<0.001)$ in nisin treated sample when compared to the control.

The use of high $\mathrm{pH}$ ( $\mathrm{pH} 10$ and 11 of $\mathrm{NaHCO}_{3}-\mathrm{NaOH}$ buffer) was shown to be very effective in the in vitro inhibition of $S$. aureus and Salmonella sp. (Fig. 3 and 4). Their growth was completely inhibited during 24 hours of incubation. The effect of $\mathrm{pH} 9$ was also significant $(\mathrm{P}<0.001)$, reducing the cell number of both pathogens by $50-60 \%$ when compared to the control. The $S$. aureus growth was significantly reduced $(\mathrm{P}<0.01)$ at $\mathrm{pH}$ 7 , while no significant differences $(\mathrm{P}>0.05)$ were observed between the growth of Salmonella sp. in the control and $\mathrm{pH} 7$ treated media (Fig. 3 and 4).

\section{Crab meat treatment}

In the experiment with $S$. aureus and Salmonella sp. inoculated crab meat, we used 600 and $100 \mu \mathrm{g} / \mathrm{mL}$ of nisin wash solution, respectively and $\mathrm{pH} 10$ sodium bicarbonate buffer The choice of the nisin concentration and $\mathrm{pH}$ level was based on their efficiency, preventing the growth of the pure cultures used, by applying the lowest efficient inhibitory concentration.

The $\mathrm{pH}$ of crab meat varied from 7.0 to 9.0 in different treatments (Table 2). We did not observe any changes in $\mathrm{pH}$ level during 5 days storage of meat at $4^{\circ} \mathrm{C}$, with the exception of nisin + EDTA treated samples.

The decrease of the counts of Salmonella sp. was observed in all treated and non-treated crab meat samples during the storage, while $S$. aureus numbers increased in all samples (Fig. 5).

ANOVA showed that the treatment and its duration affected significantly the growth of $S$. aureus and Salmonella $\mathrm{sp}$. inoculated in crab meat (Table 3). We found that nisin was not effective in preventing growth of $S$. aureus and Salmonella sp. in crab meat (Fig. 5). On the other hand, $\mathrm{pH} 10 \mathrm{NaHCO}_{3}-\mathrm{NaOH}$ buffer showed significant inhibitory effect $(\mathrm{P}<0.05)$ on Salmonella sp., but not on S. aureus, inoculated into the crab meat. 


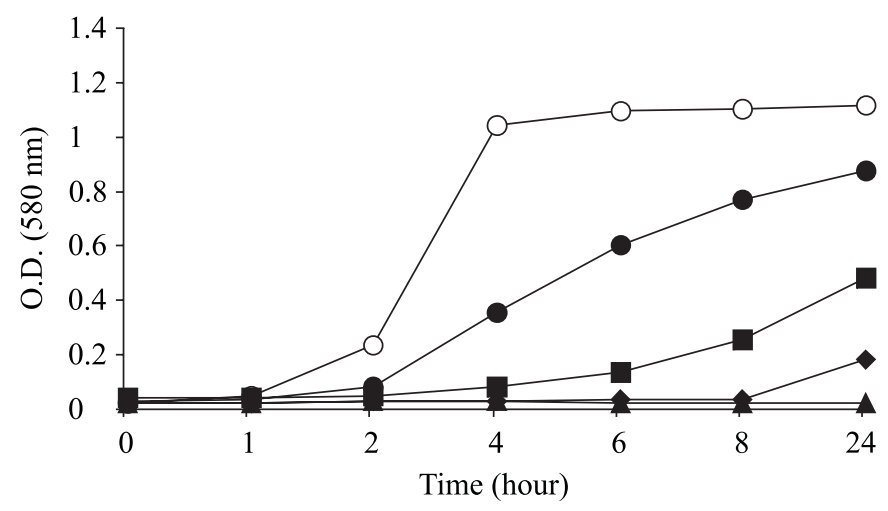

Figure 3. Growth of Staphylococcus aureus in BHI broth reconstituted in distilled water (control) $(\mathrm{O})$ and in $\mathrm{NaHCO}_{3}$ $\mathrm{NaOH}$ buffer at different pHs: $7.0(\bullet), 9.0(\square), 10.0(\diamond)$, and $11.0(\mathbf{\Delta})$.

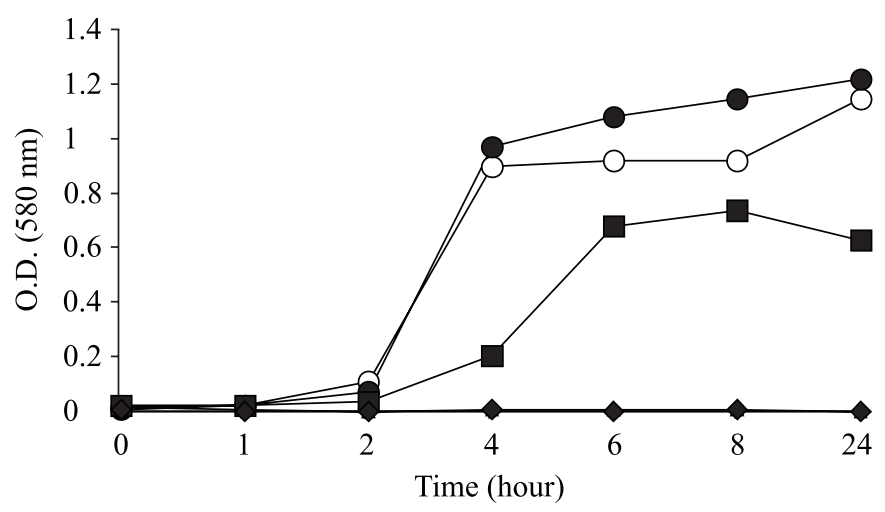

Figure 4. Growth of Salmonella sp. in BHI broth reconstituted in distilled water (control) $(\mathrm{O})$ and in $\mathrm{NaHCO}_{3}-\mathrm{NaOH}$ buffer at different pHs: $7.0(\bullet), 9.0(\boldsymbol{\square}), 10.0(\diamond)$, and 11.0( $\mathbf{(})$.
Table 2. Values of $\mathrm{pH}$ of the crab meat samples treated with nisin and $\mathrm{NaHCO}_{3}-\mathrm{NaOH}$ buffer at $\mathrm{pH}$ 10.0.

\begin{tabular}{ccc}
\hline & \multicolumn{2}{c}{$\mathrm{pH}$} \\
\cline { 2 - 3 } Crab meat sample & \multicolumn{2}{c}{ Storage at $4^{\circ} \mathrm{C}$ (days) } \\
\cline { 2 - 3 } & 0 & 5 \\
\hline Frozen & 8.25 & - \\
$\mathrm{H}_{2} \mathrm{O}$ distilled-treated & 8.25 & 8.25 \\
Nisin-treated & 8.00 & 8.00 \\
Nisin + EDTA-treated & 7.00 & 7.50 \\
pH 10- treated & 9.00 & 9.00 \\
\hline
\end{tabular}

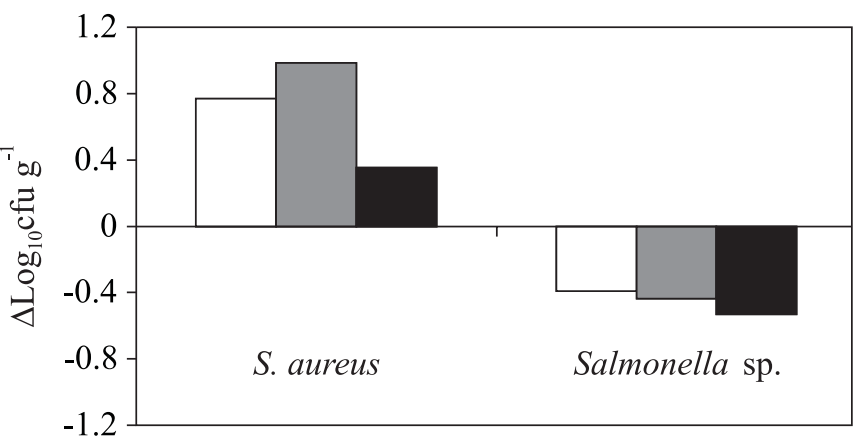

Figure 5. Effect of preservation agents on survival of Staphylococcus aureus and Salmonella sp. in the samples of crab meat stored for 5 days at $4^{\circ} \mathrm{C}:(\square)$ washed with distilled water (control), ( $\square$ ) washed with $600 \mu \mathrm{g} / \mathrm{ml}$ of nisin (S. aureus) or $100 \mu \mathrm{g} / \mathrm{ml}$ of nisin and $20 \mathrm{mM}$ EDTA (Salmonella sp.),

washed with $\mathrm{NaHCO}_{3}-\mathrm{NaOH}$ buffer at $\mathrm{pH} 10.0 . \Delta \log _{10} \mathrm{cfu} \mathrm{g}{ }^{-1}$ : difference between the bacterial counts before washing and after 5 days storage of washed crab meat.
Table 3. Results of two-way ANOVA on the S. aureus and Salmonella sp. growth in crab meat treatment experiment.

\begin{tabular}{|c|c|c|c|c|c|c|c|c|}
\hline \multirow[t]{2}{*}{ Variable } & \multicolumn{4}{|c|}{ S. aureus } & \multicolumn{4}{|c|}{ Salmonella sp. } \\
\hline & df & MS & F & $\mathrm{P}$ & df & MS & F & $\mathrm{P}$ \\
\hline Treatment & 2 & 64.623 & 4.165 & $0.029 *$ & 2 & 53.215 & 97.27 & $0.000^{*}$ \\
\hline Time & 6 & 97.753 & 6.300 & $0.001 *$ & 6 & 36.723 & 67.13 & $0.000^{*}$ \\
\hline $\begin{array}{l}\text { Treatment } \\
\mathrm{x} \text { Time }\end{array}$ & 12 & 71.563 & 4.612 & $0.001 *$ & 12 & 4.968 & 9.08 & $0.000^{*}$ \\
\hline
\end{tabular}

Mean Squares (MS) and F values are indicated with degrees of freedom (df); * Significant at $1 \%$ level.

\section{DISCUSSION}

Crab meat is sold commonly as a pre-cooked meat, which can provide a suitable environment for proliferation of meat spoilage microorganisms and common food-borne pathogens, including S. aureus and Salmonella species $(2,9,13)$. Degnan et al. (5) analyzed fresh meat of the blue crab (Callinectes sapidus) highly contaminated with total bacteria (mean value $5.1 \log _{10} \mathrm{CFU} / \mathrm{g}$ ) and with Listeria monocytogenes. The meat of $U$. cordatus obtained in free markets in Northeast Brazil showed a high contamination level of total bacteria $\left(10^{8}-10^{9} \mathrm{CFU} / \mathrm{g}\right)$ 
and of S. aureus $\left(10^{4}-10^{8} \mathrm{CFU} / \mathrm{g}\right)$. S. aureus was detected in $63 \%$ of the meat samples, whereas contamination with Salmonella sp. was found in $8 \%$ of the samples (10). Chen et al. (4) also detected high numbers of total bacteria (5.2 $\log _{10} \mathrm{CFU} /$ g) and of $S$. aureus $\left(5.0 \log _{10} \mathrm{CFU} / \mathrm{g}\right)$ in crab meat samples produced industrially. These data show that there is a need for improving sanitary conditions of meat handling and processing, by using some preservatives that could be easily applied in both large and small-scale productions of crab meat.

Information on application of antibacterial agents for preservation of crab meat is scarce. Degnan et al. (5) showed that numbers of Listeria monocytogenes inoculated into the crab meat of $C$. sapidus decreased after 4 hours of incubation at $4^{\circ} \mathrm{C}$ when washed with nisin $(10,000$ and 20,000 units $/ \mathrm{mL})$, maintaining the inhibition effect during 6 days of the experiment.

Scanell et al. (14) reported that the growth of S. kentucky in culture was inhibited by nisin in the concentration of $500 \mathrm{IU} / \mathrm{g}$ over 10 hours incubation at $37^{\circ} \mathrm{C}$ and in fresh sausage stored for 10 days at $4^{\circ} \mathrm{C}$. The inhibition of S. aureus under the treatment with $500 \mathrm{IU} / \mathrm{g}$ of nisin solely or in combination with $1.5-2.0 \%$ sodium lactate and $1 \%$ sodium citrate was also observed (14). Stevens et al. (16) reported that cell number of twenty Salmonella species was reduced by applying the $50 \mathrm{mg} / \mathrm{mL}$ of nisin and $20 \mathrm{mM}$ of EDTA for 1 hour at $37^{\circ} \mathrm{C}$.

In the present study, strong inhibitory effect of nisin, as well as high $\mathrm{pH}$ on S. aureus and Salmonella sp. in broth culture was observed. However, the chemical agents applied to the contaminated crab meat were not very effective in reducing cell numbers of these pathogens.

The effect of nisin can be influenced by $\mathrm{pH}$, the culture medium and the incubation temperature. Huot et al. (7) reported that nisin showed the highest antibacterial activity at $\mathrm{pH} 5.8$, and that its activity decreased by $1.4 \%$ and $49.0 \%$ at $\mathrm{pH} 6.4$ and 7.2, respectively. Thomas and Wimpenny (19) found that the nisin's effectiveness appeared to increase with the decrease of $\mathrm{pH}$ in the range $\mathrm{pH} 7.9$ to 5.0.

In our experiment, where the initial $\mathrm{pH}$ of the control and treatment media was 7.5 and decreased to 6.0 after 24 hours of incubation, the nisin effectively prevented the growth of bacterial pathogens in pure cultures. However, the low efficiency of nisin in reducing the number of pathogens in crab meat could be explained partially by the influence of high $\mathrm{pH}$ level of nisin treated samples (pH 7 to 8), as well as a high buffer capacity of the crab meat.

High $\mathrm{pH}$ treatment has already been shown to be effective in the destruction of $S$. enteritidis on shell eggs (3). Application of this technology to agricultural commodities, such as raw meats, poultry, and plant products, may offer simple and highly effective means for destroying gram-negative food-borne pathogens and thus improving the safety of these valuable foods.

Mendonça et al. (12) observed total reduction, in culture medium, of Salmonella enteritidis cells after five minutes treatment with buffer at $\mathrm{pH} 11$; after fifteen minutes treatment with buffer at $\mathrm{pH} 10$ the number of viable cells decreased by $1 \mathrm{x}$ $10^{4} \mathrm{CFU} / \mathrm{mL}$, and at $\mathrm{pH} 9$ it had no effect. In other study, the $\mathrm{NaHCO}_{3}-\mathrm{NaOH}$ buffer at $\mathrm{pH} 7$ and 10 decreased partially the growth of S. enteritidis and completely at $\mathrm{pH} 11$ (18).

In our study, $\mathrm{pH} 10$ and 11 of $\mathrm{NaHCO}_{3}-\mathrm{NaOH}$ buffer inhibited completely the growth of S. aureus and Salmonella sp. over 24 hours of incubation. The buffer at $\mathrm{pH} 10$ showed also significant inhibitory activity on Salmonella sp., when applied to contaminated crab meat. It should be pointed out that the $\mathrm{pH}$ of the crab meat treated with the $\mathrm{pH} 10$ buffer stabilized at the level of $\mathrm{pH} 9$, due to the buffering capacity of the meat.

Our results suggest that the use of high $\mathrm{pH}$, before freezing, would be an alternative to decrease the contamination level of crab meat. There is a need, however, for further research on high $\mathrm{pH}$ effect on crab meat contaminating bacteria, as well as, on sensorial properties of the treated meat, an aspect not deemed in the present work.

\section{RESUMO}

\section{Ação da nisina e do pH elevado sobre a multiplicação de Staphylococcus aureus e Salmonella sp. em cultura pura e em carne de caranguejo-uçá (Ucides cordatus)}

O objetivo deste estudo foi avaliar o potencial de inibição de nisina e o pH elevado em relação à multiplicação de Staphylococcus aureus e Salmonella sp. em culturas puras e inoculadas na carne de caranguejo-uçá. Em culturas puras, a multiplicação de $S$. aureus foi fortemente inibida por nisina e a de Salmonella sp. por nisina-EDTA (20 mM). A multiplicação de $S$. aureus foi inibida até $8 \mathrm{~h}$ de incubação, enquanto que a de Salmonella sp. foi inibida durante todo o experimento (24h). O pH elevado (tampão $\mathrm{NaHCO}_{3}-\mathrm{NaOH}, \mathrm{pH} 10$ e 11) mostrou-se efetivo na inibição da multiplicação de $S$. aureus e Salmonella sp. Nisina e o pH elevado aplicados na carne contaminada não apresentaram o mesmo efeito. A nisina não mostrou eficiência na inibição dos patógenos quando inoculados na carne de caranguejo, enquanto que o tampão em pH 10 demonstrou inibição significante sobre a multiplicação de Salmonella sp. Estes resultados sugerem que o $\mathrm{pH}$ elevado apresenta um potencial como agente antibacteriano, podendo ser útil na preservação química da carne de caranguejo.

Palavras-chave: carne de caranguejo, nisina, $\mathrm{pH}$ elevado, Staphylococcus aureus e Salmonella sp.

\section{REFERENCES}

1. Abee, T.; Rombouts, F.M.; Hugenholtz, J.; Guihard, G.; Letellier, L. Mode of action of nisin $\mathrm{Z}$ against Listeria monocytogenes Scott A grown at high and low temperatures. Appl. Environ. Microbiol., 60, 1962-1968, 1994. 
2. Ayulo, A.M.R.; Machado, R.A.; Scussel, V.M. Enterotoxigenic Escherichia coli and Staphylococcus aureus in fish and seafood from the Southern region of Brazil. Int. J. Food Microbiol., 24, 171-178, 1994.

3. Catalano, C.R.; Knabel S.J. Incidence of Salmonella in Pennsylvania egg processing plants and destruction by high pH. J. Food Prot., 57, 587-591, 1994

4. Chen, Y.P.; Andrews, L.S.; Grodner, R.M. Sensory and microbial quality of irradiated crab meat products. J. Food Sci., 61, 1239-1242, 1996.

5. Degnan, A.J.; Kaspar, C.W.; Otwell, W.S.; Tamplin, M.L.; Luchansky, J.B. Evaluation of lactic acid bacterium fermentation products and foodgrade chemicals to control Listeria monocytogenes in blue crab (Callinectes sapidus) meat. Appl. Environ. Microbiol., 60, 3198-3203, 1994.

6. Delves-Broughton, J.; Williams, G.C.; Wilkinson, S. The use of the bacteriocin nisin as a preservative in pasteurized liquid whole egg. Lett. Appl. Microbiol., 15, 133-136, 1990.

7. Huot, E.; Barrena-Gonzalez, C.; Petitdemange, H. Comparative effectiveness of nisin and bacteriocin $\mathrm{J} 46$ at different $\mathrm{pH}$ values. Lett. Appl. Microbiol., 22, 76-79, 1996.

8. Laird, J.M.; Bartlett F.M.; McKellar, R.C. Survival of Listeria monocytogenes in egg washwater. Int. J. Food Microbiol., 12, 115$122,1991$.

9. Lee, J.S.; Preifer, D.K. Microbiological characteristics of dungness crab (Cancer magister). Appl. Microbiol., 30, 72-78, 1975.

10. Lima T.C.S.; Gorlach-Lira, K. The occurrence of coliform bacteria, Staphylococcus aureus and Salmonella spp. in the land crab meat (Ucides cordatus) from the free markets at the Paraiba State. XX Congresso Brasileiro de Microbiologia, Salvador, 1999, p.349.

11. Martinis, E.C.P.; Crandall, A.D.; Mazzotta, A.S.; Montville, T.J. Influence of $\mathrm{pH}$, salt and temperature on nisin resistance in Listeria monocytogenes. J. Food Prot., 60, 420-423, 1997.
12. Mendonca, A.F.; Amoroso, T.L.; Knabel, S.J. Destruction of Gramnegative food-borne pathogens by high $\mathrm{pH}$ involves disruption of the cytoplasmic membrane. Appl. Environ. Microbiol., 60, 40094014, 1994.

13. Reinhard, R.G.; McAdams, T.J.; Flick, G.J.; Wittman, R.F.; Croonenberghs, R.E.; Diallo, A.A. Qualitative and quantitative analysis of Campylobacter jejuni and Campylobacter coli in fresh blue crab (Callinectes sapidus) meat. J. Aqu. Food Prod. Technol., 4, 31-36, 1995

14. Scanell, A.G. M.; Hill, C.; Buckley, D.J.; Arendt, E.K. Determination of the influence of organic acids and nisin on shelf-life and microbiological safety aspects of fresh pork sausage. J. Appl. Microbiol., 83, 407-412, 1997.

15. Southam G.; Pearson J.; Holley, P.A. Survival and growth of Yersinia enterocolitica in egg washwater. J. Food Prot., 50, 103-107, 1987.

16. Stevens, K.A.; Sheldon, B.W.; Klapes, N.A.; Klaenhammer, T.R. Nisin treatment for inactivation of Salmonella species and other Gram-negative bacteria. Appl. Environ. Microbiol., 57, 3613-3615, 1991.

17. Stevens, KA.; Sheldon, B.W.; Klapes, N.A.; Klaenhammer, T.R. Effect of treatment conditions on nisin inactivation of Gramnegative bacteria. J. Food Prot., 55, 763-766, 1992.

19. Teo, Y-L.; Raynor, T.J.; Ellajosyula, K.R.; Knabel, S.J. Synergistic effect to high temperature and high $\mathrm{pH}$ on the destruction of Salmonella enteretidis and Escherichia coli O157:H7. J. Food Prot., 59, 1023-1030, 1996.

18. Thomas, L.V.; Wimpenny, J.W. Investigation of the effect of combined variations in temperature, $\mathrm{pH}$, and $\mathrm{NaCl}$ concentration on nisin inhibition of Listeria monocytogenes and Staphylococcus aureus. Appl. Environ. Microbiol., 62, 2006-2012, 1996. 